\title{
Cimetidine: prophylaxis against upper gastrointestinal haemorrhage after renal transplantation
}

\author{
R H JONES, C J RUDGE, M BEWICK, V PARSONS, M J WESTON
}

British Medical fournal, 1978, 1, 398-400

\section{Summary and conclusions}

The incidence of upper gastrointestinal haemorrhage within four months of renal transplantation was studied in two groups of patients. Thirty patients who received prophylactic cimetidine suffered no episodes of upper gastrointestinal haemorrhage, while six of the 33 patients who did not receive cimetidine suffered haemorrhages and one of them died as a result. The difference between the groups was significant.

The results suggest that the prophylactic use of cimetidine in patients receiving renal transplants is worth while.

\section{Introduction}

Peptic ulceration, upper gastrointestinal haemorrhage, and gastric and duodenal perforation occur in $4^{\circ}{ }_{0}$ to $22^{\circ}{ }_{\circ}$ of renal transplant recipients. ${ }^{1-5}$ The mortality of these conditions is commonly over $50^{\circ}{ }^{1}{ }^{5-7}$ and may account for $7 \cdot 5^{\circ}$ of all deaths in these patients. ${ }^{8}$

Among possible measures for reducing the incidence of these complications prophylactic surgery is difficult to justify. Pretransplant findings correlate poorly with the development of post-transplant gastrointestinal lesions,,$^{3469}$ although elective surgery has been recommended in patients awaiting renal transplantation who have peptic ulceration because the incidence of gastrointestinal haemorrhage after transplantation may thereby be reduced. ' An intensive antacid regimen hastens the healing of duodenal ulcer, ${ }^{10}$ and there is some evidence that antacids prevent the development of gastric erosions in patients admitted to intensive care units ${ }^{11}$ and in patients with fulminant hepatic failure. ${ }^{12}$ The results of recent controlled trials ${ }^{13}$ in patients with fulminant hepatic failure are, however, at odds with this view.

Histamine $\mathrm{H}_{2}$-receptor antagonists are potent inhibitors of gastric acid secretion, ${ }^{14}{ }^{15}$ and gastric acid may be a prerequisite in the pathogenesis of gastric erosions. ${ }^{16}{ }^{17}$ The role of gastric acid in duodenal ulceration is established, and $\mathrm{H}_{2}$-receptor antagonists hasten the healing of duodenal ${ }^{1819}$ and benign

King's College Hospital Renal Unit, Dulwich Hospital, London SE22 R H JONES, MA, MRCP, renal registrar

C J RUDGE, BSC, FRCS, honorary senior registrar

$M$ BEWICK, FRCS, honorary consultant surgeon

V PARSONS, DM, FRCP, consultant physician

M J WESTON, MA, MRCP, consultant physician gastric $^{20}$ ulcers. There is also evidence that, at least in men, renal transplantation is followed by a significant rise in peak acid output. ${ }^{6}$ Furthermore, continued damage to the mucosa is probably mediated by mast-cell histamine, ${ }^{21}{ }^{22}$ and raised concentrations in blood and urine have been shown after renal transplantation. ${ }^{23}$ We therefore decided to assess the place of a histamine $\mathrm{H}_{2}$-receptor antagonist cimetidine in the management of patients undergoing renal transplantation.

\section{Patients and methods}

Thirty-five consecutive patients who received cimetidine after transplantation were studied prospectively. The incidence of gastrointestinal haemorrhage was compared with that in the previous 35 transplant recipients, who had not received cimetidine.

Three of the treated patients died in the first week after transplantation (two from myocardial infarction and one from anaphylactic reaction to antilymphocyte globulin) and two developed generalised mucosal haemorrhage due to septicaemia and proved coagulopathy. One untreated patient died 24 hours after operation, and another died from generalised mucosal bleeding due to pancreatitis, septicaemia, and coagulopathy. These seven patients were excluded from further analysis, leaving a total of 63 (table I).

There was no significant difference between the groups in the numbers of patients with delayed graft function or the occurrence of post-transplant problems such as septicaemia, acute rejection, and surgical complications. Patient survival at four months was $70 \%$ in each group, and of those that died, about $25 \%$ in each group died with a functioning transplant.

The renal transplants were performed by two surgeons in the same unit over 17 months. Immediately after transplantation all patients received the following immunosuppressive regimen: (a) prednisone or prednisolone (or hydrocortisone equivalent) was given in a dose of $200 \mathrm{mg}$ /day for three days, $150 \mathrm{mg} /$ day for three days, $100 \mathrm{mg} /$ day for three days, and reducing to a dose of about $20-25 \mathrm{mg} /$ day at four months; (b) daily azathioprine was given in a dose of $2 \mathrm{mg} / \mathrm{kg} /$ day adjusted according to the white blood cell and platelet counts; $(c)$ antilymphocyte globulin was given to 10 patients in the untreated group and 13 in the treated group; $(d)$ acute rejection was treated with intravenous doses of $1 \mathrm{~g}$ methylprednisolone on three successive days augmented, when necessary, by a three-day course of actinomycin D and radiotherapy.

Cimetidine was given immediately the patient returned from the theatre, and the starting dose for all patients was $200 \mathrm{mg}$ intravenously every 12 hours; this regimen was continued orally when appropriate. When renal function began to improve the dose was increased to 200 mg every eight hours and to the more usual regimen of $200 \mathrm{mg}$ thrice daily and $400 \mathrm{mg}$ at night when the serum creatinine concentration fell below $300: \mathrm{mol} / \mathrm{l}(3 \cdot 4 \mathrm{mg} / 100 \mathrm{ml})$. All patients received cimetidine for four to six weeks apart from two patients who left hospital within a fortnight of the transplant. Two patients with newly diagnosed duodenal ulceration were treated with cimetidine for three weeks before transplantation.

Patients receiving cimetidine did not routinely receive antacids. The untreated patients were given aluminium hydroxide suspension (Aludrox) $10-20 \mathrm{ml}$ every four hours, changing to $7.5 \%$ aluminium

TABLE I-Details of patients studied

\begin{tabular}{|c|c|c|c|c|c|c|c|c|c|c|c|}
\hline & \multirow{2}{*}{$\begin{array}{l}\text { Total } \\
\text { No }\end{array}$} & \multicolumn{2}{|r|}{ Men } & \multicolumn{2}{|r|}{ W'omen } & \multicolumn{4}{|c|}{ No with blood group: } & \multicolumn{2}{|c|}{ No given: } \\
\hline & & No & $\begin{array}{c}\text { Mean age } \\
\text { (range) in years }\end{array}$ & No & $\begin{array}{c}\text { Mean age } \\
\text { (range) in years }\end{array}$ & $\mathrm{O}$ & $\mathrm{A}$ & B & $\mathrm{AB}$ & $\begin{array}{c}\text { Cadaver } \\
\text { transplants }\end{array}$ & $\begin{array}{l}\begin{array}{c}\text { Live-related } \\
\text { transplants }\end{array} \\
\end{array}$ \\
\hline $\begin{array}{l}\text { Untreated } \\
\text { Treated }\end{array}$ & $\begin{array}{l}33 \\
30\end{array}$ & $\begin{array}{l}22 \\
17\end{array}$ & $\begin{array}{l}37(18-62) \\
39(17-71)\end{array}$ & $\begin{array}{l}11 \\
13\end{array}$ & $\begin{array}{l}45(26-57) \\
44(17-64)\end{array}$ & $\begin{array}{l}16 \\
11\end{array}$ & $\begin{array}{l}15 \\
12\end{array}$ & $\begin{array}{l}2 \\
5\end{array}$ & $\begin{array}{l}0 \\
2\end{array}$ & $\begin{array}{l}29 \\
25\end{array}$ & $\begin{array}{l}4 \\
5\end{array}$ \\
\hline
\end{tabular}


TABLE II-Results of gastrointestina! investigations

\begin{tabular}{|c|c|c|c|c|c|c|c|c|c|}
\hline & \multirow{2}{*}{$\begin{array}{c}\text { No } \\
\text { examined }\end{array}$} & \multirow{2}{*}{$\begin{array}{l}\text { Normal upper } \\
\text { gastrointestinal } \\
\text { tract }\end{array}$} & \multicolumn{2}{|c|}{ Hiatus hernia } & \multirow{2}{*}{$\begin{array}{l}\text { Gastric } \\
\text { ulcer }\end{array}$} & \multirow{2}{*}{$\begin{array}{l}\text { Duodenal } \\
\text { ulcer }\end{array}$} & \multirow{2}{*}{$\begin{array}{l}\text { Giant rugal } \\
\text { hypertrophy }\end{array}$} & \multirow{2}{*}{$\begin{array}{l}\text { Generalised } \\
\text { gastritis and } \\
\text { duodenitis }\end{array}$} & \multirow{2}{*}{$\begin{array}{c}\text { Oesophagea } \\
\text { varices }\end{array}$} \\
\hline & & & Alone & With reflux & & & & & \\
\hline $\begin{array}{l}\text { Untreated } \\
\text { Treated }\end{array}$ & $\begin{array}{l}23 \\
24\end{array}$ & $\begin{array}{l}15 \\
14\end{array}$ & $\begin{array}{l}3 \\
1\end{array}$ & $\begin{array}{l}2 \\
3 *\end{array}$ & $0^{1+}$ & $\begin{array}{l}1+ \\
4+\end{array}$ & $\begin{array}{l}1 \\
0\end{array}$ & $\begin{array}{l}0 \\
1\end{array}$ & $\begin{array}{l}0 \\
1\end{array}$ \\
\hline
\end{tabular}

*Includes case of active peptic oesophagitis endoscopically diagnosed at the time of transplantation. $\quad+$ Diagnosed 3-4 months before transplant and treated medically. $\quad \ddagger$ One patient had an ulcer diagnosed 2 years before transplantation: it was treated medically; one underwent highly selective vagotomy two years before transplantation; one had an active ulcer discovered 3 weeks before transplantation and was given cimetidine; the fourth also had cimetidine after suffering a major gastrointestinal haemorrhage 3 weeks before transplantation.

TABLE III-Details of patients from untreated group with gastrointestinal haemorrhage

\begin{tabular}{|c|c|c|c|c|c|c|c|c|c|}
\hline $\begin{array}{l}\text { Case } \\
\text { No }\end{array}$ & Age & Sex & $\begin{array}{l}\text { Blood } \\
\text { group }\end{array}$ & Cause of renal failure & $\begin{array}{l}\text { Pretransplant barium } \\
\text { meal examination }\end{array}$ & $\begin{array}{c}\text { Time after } \\
\text { transplant of } \\
\text { haemorrhage }\end{array}$ & Presentation & $\begin{array}{l}\text { Endoscopic and } \\
\text { radiological findings }\end{array}$ & Outcome \\
\hline 1 & 32 & M & $\mathrm{O}$ & Diabetes mellitus & $\begin{array}{l}\text { Giant rugal } \\
\text { hypertrophy }\end{array}$ & 4 days & $\begin{array}{l}\text { Haematemesis and } \\
\text { melaena }\end{array}$ & Gastric erosions & Died \\
\hline 2 & 52 & M & A & $\begin{array}{l}\text { Analgesic nephropathy, } \\
\text { chronic pvelonephritis }\end{array}$ & Not done & 6 days & $\begin{array}{l}\text { Haematemesis and } \\
\text { melaena }\end{array}$ & $\begin{array}{l}\text { Normal barium meal } \\
\text { (no endoscopy) }\end{array}$ & Survived \\
\hline 3 & 43 & M & $\mathrm{O}$ & $\begin{array}{l}\text { Ankylosing spondylitis and } \\
\text { radiation nephritis }\end{array}$ & $\begin{array}{l}\text { Duodenal ulcer } 3 \\
\text { months before } \\
\text { transplant }\end{array}$ & 2 weeks & Haematemesis & $\begin{array}{l}\text { Oesophagitis, gastric } \\
\text { erosions }\end{array}$ & Survived \\
\hline 4 & 29 & $\mathrm{~F}$ & A & $\begin{array}{l}\text { Vesicoureteric reflux and } \\
\text { chronic pyelonephritis }\end{array}$ & Not done & 6 weeks & $\begin{array}{l}\text { Haematemesis and } \\
\text { melaena }\end{array}$ & Two duodenal ulcers & Survived \\
\hline 5 & 32 & $\mathrm{~F}$ & A & Diabetes mellitus & Not done & 9 weeks & $\begin{array}{l}\text { Haematemesis and } \\
\text { melaena }\end{array}$ & $\begin{array}{l}\text { Oesophageal and } \\
\text { gastric erosions }\end{array}$ & Survived \\
\hline 6 & 52 & $\mathrm{~F}$ & $\mathrm{O}$ & Hypertension & Normal & 10 weeks & Melaena & Acute duodenal ulcer & Survived \\
\hline
\end{tabular}

phosphate gel (Aluphos) when hypophosphataemia occurred. No attempt was made to titrate dosage against gastric acidity.

\section{INVESTIGATIONS}

Before transplantation-All patients from our own unit underwent barium meal examination before transplantation and, when available, this information was obtained from other units that had transferred patients for transplantation (table II). Upper gastrointestinal fibreoptic endoscopy was performed by one of us ( $\mathrm{RHJ}$ ) on nine patients in the treated group. Six underwent endoscopy at the time of transplantation and three were examined before transplantation because of clinical or radiological indications.

After transplantation-Daily investigations included white cell and platelet counts, and estimations of haemoglobin, urea, electrolyte, and serum creatinine concentrations. Calcium, phosphate, magnesium, and serum protein concentrations and liver function were estimated twice weekly. Faecal occult blood and coagulation screens were performed when appropriate. Patients in the treated group with endoscopically confirmed lesions underwent repeat endoscopy six weeks after transplantation.

Gastrointestinal haemorrhage--This was defined as the occurrence of haematemesis or melaena, or both, and a fall in haemoglobin. In the untreated group this information was obtained from the patient's case notes but the treated group was studied prospectively.

\section{Results}

There was no evidence of overt or occult blood loss in the treated group, but acute upper gastrointestinal haemorrhage occurred in six patients in the untreated group (table III; $\mathrm{P}=0.016$, Fisher's exact test). These patients were managed conservatively, and one died as a result of blood loss; none showed any evidence of any clotting disorder. There were no other upper gastrointestinal tract complications in either group. Two episodes of colonic bleeding occurred, one in each group.

Of the six patients in the treated group who underwent endoscopy at transplantation, one had active peptic oesophagitis and the other five were normal. In the three other patients in this group, who underwent endoscopy before transplantation because of haematemesis, a history of duodenal ulceration, and barium-negative dyspepsia, the findings were, respectively, acute duodenal ulceration, chronic duodenal ulceration, and a normal upper gastrointestinal tract (see table II). Repeat endoscopy six weeks after transplantation and treatment with cimetidine in the three patients with positive findings showed satisfactory healing of the lesions.

Cimetidine was well tolerated; one patient with diabetes mellitus developed troublesome vomiting shortly after transplantation, which ceased when several drugs, including cimetidine, were withdrawn, but no other side effects were noted, and no adverse changes in haematological or biochemical values were apparent.

\section{Discussion}

There is a striking difference between the incidence of and morbidity and mortality from peptic ulceration before and after renal transplantation. ${ }^{6}$ Early reports of a high incidence of peptic ulcer disease in uraemic patients ${ }^{24}{ }^{25}$ are suspect because the diagnostic criteria were unreliable. ${ }^{26}$ The incidence is probably no greater than that found in age-matched controls among the general population. ${ }^{6} 2{ }^{2 \times}$ After renal transplantation, however, the incidence of peptic ulcer disease may be as high as $22^{\circ}{ }^{6}{ }^{6}$; moreover, gastrointestinal haemorrhage from these lesions carries a high mortality, often over $50^{\circ} \ldots 0^{15-;}$ We have shown here that cimetidine, routinely administered after renal transplantation, significantly reduces the incidence of gastrointestinal haemorrhage.

Upper gastrointestinal complications of transplantation may occur years after the transplant but most occur within the first four months. ${ }^{2} 6$; Haemorrhage is the commonest complication and occurs from gastric, oesophageal, or duodenal erosions in the first week or so, when immunosuppression is maximal, and later from similar lesions in patients who become seriously ill from sepsis, rejection and its treatment, and surgical or other complications. A third group of patients develop more localised peptic ulceration, usually pyloric or duodenal, after about six weeks. Bleeding from a single gastric ulcer after transplantation is distinctly uncommon. ${ }^{6}$ Our experience corresponds with this (see table III).

Since the presence of gastric acid is of central importance in the pathogenesis of these lesions, ${ }^{13}{ }^{17}$ reduction in gastric acid secretion might be expected to influence their development, and the possible role of histamine $e^{21-23}$ as a mediator of mucosal injury reinforces the rationale for using an $\mathrm{H}_{2}$-receptor antagonist. Cimetidine has been shown to be effective in preventing acute upper gastrointestinal haemorrhage in fulminant hepatic failure ${ }^{13}$; so long as intragastric $\mathrm{pH}$ was maintained above 5 bleeding was almost totally eliminated. The therapeutic role of cimetidine in duodenal ulceration is established, ${ }^{1 \times 19}$ and recent reports show that it also hastens the healing of benign gastric ulcers. ${ }^{20}$ The increase in mean peak acid output after renal transplantation, however, is significantly increased in men but not in women. ${ }^{6}$ None the less, half of our patients who 
developed upper gastrointestinal haemorrhage, $33^{\circ}{ }_{0}$ of those in the study of Chisholm et al (1977), and $44^{\circ}{ }^{\circ}$ of those in the study of Hadjiyannakis et al (1971) were women, which suggests that other factors play a part.

It has been suggested that administration of corticosteroids may damage the gastric mucosa ${ }^{29}$ or impair the resistance of the mucosal barrier to injury. ${ }^{3}$ A significantly higher incidence of peptic ulceration was observed in a large series of patients with rheumatoid arthritis treated with steroids, ${ }^{27}$ and the recent findings of McGeown et al (1977) in renal transplant recipients reinforces this view. With a starting dose of prednisone of only $20 \mathrm{mg}$ day after transplantation only one out of 100 patients died from upper gastrointestinal haemorrhage.

The treated and untreated groups were well matched for age, sex, and blood group and the immunosuppressive regimen was standardised throughout the study. The high incidence $\left(18^{\circ}{ }_{0}\right)$ of gastrointestinal haemorrhage in the untreated group may reflect the steroid dosage used. No other symptomatic upper gastrointestinal tract complications occurred in either group, however, which compares favourably with the results in other series, in which symptomatic peptic ulceration has occurred in up to $22^{\circ}{ }_{0}$ of patients. ${ }^{6}$ The overall mortality in the untreated group was low at $3^{\circ}{ }_{0}$, and among those who bled, the mortality was only $16^{\circ}$.

None of the patients who had previously diagnosed (and medically treated) peptic ulceration but did not receive cimetidine bled, but the patient with giant rugal hypertrophy died from his gastrointestinal haemorrhage. The endoscopic confirmation of healing in the patients in the treated group who were known to have active lesions shortly before transplantation is encouraging, and cimetidine may have a therapeutic as well as prophylactic part to play in managing established peptic ulceration in transplant recipients.

Cimetidine is excreted by the kidneys; in the presence of delayed graft function $200 \mathrm{mg}$ of cimetidine given every 12 hours will produce therapeutic blood concentrations until renal function begins to improve. ${ }^{30}$ The drug appears to be completely cleared by haemodialysis. ${ }^{30}$ Recent reports ${ }^{31}{ }^{32}$ of central nervous system and other side effects (mental confusion, agitation, flushing, and sweating), possibly related to overdose, are worrying, but none were observed in our patients. No other adverse effects attributable to the drug were observed, either clinically or in terms of haematological or biochemical values.
We therefore consider that cimetidine, administered routinely after renal transplantation, promises to be an effective and safe prophylactic agent against upper gastrointestinal complications. Further trials and longer follow-up of its efficacy are indicated.

\section{References}

${ }^{1}$ Moore, T C, and Hume, D M, Annals of Surgery, 1969, 170, 1.

Hadiivannakis, E J, et al, Lancet, 1971, 2, 782.

${ }^{3}$ Coleman, M J, et al, Medical fournal of Australia, 1972, 1, 546.

${ }^{4}$ Penn, I, et al, Annals of Surgery, 1968, 168, 865.

5 Libertino, J A, Zinman, L, and Dowd, J B, Surgical Clinics of North America, 1971, 81, 733 .

${ }^{6}$ Chisholm, G D, et al, British Medical fournal, 1977, 1, 1630.

Owens, M L, et al, Annals of Surgery, 1977, 186, 17. Association, 1973, 10, 17.

${ }^{9}$ Hampers, C L, et al, Long-Term Haemodialysis, p 144. New York, Grune and Stratton, 1973

1" Peterson, W L, et al, New England Fournal of Medicine, 1977, 297, 341.

${ }_{11}$ Silen, W, and Skillman, J J, Advances in Internal Medicine, 1972, 19, 195.

${ }^{12}$ Opolon, P, and Caroli, J, Médicine et Hygiène, 1974, 32, 159.

${ }^{13}$ MacDougall, B R D, et al, Lancet, 1977, 1, 617.

${ }^{14}$ Black, J W, et al, Nature, 1972, 236, 385.

15 Pounder, R E, et al, Gut, 1975, 16, 397. Cimetidine, ed W R . Excerpta Medica, 1977.

17 Moody, F G, et al, American fournal of Digestive Disease, 1976, 21, 148.

${ }^{18}$ Bodemar, G, and Walan, A, Lancet, 1976, 2, 161.

${ }^{19}$ Gray, G R, et al, Lancet, 1977, 1, 4.

${ }^{20}$ Frost, F, et al, British Medical fournal, 1977, 2, 795.

21 Johnson, L R, Gastroenterology, 1968, 54, 8.

2:2 Davenport, $\mathrm{H} \mathrm{W}$, in Progress in Gastroenterology, vol II, ed G Jerzy-Glass, p 42. New York, Grune and Stratton, 1970

${ }^{23}$ Moore, T C, Thompson, D F, and Glassock, R J, Annals of Surgery, 1971, $173,381$.

${ }^{24}$ Comty, C M, Baillod, R A, and Shaldon, S, Proceedings of the European Dialysis and Transplant Association, 1965, 2, 88.

${ }^{25}$ Pendras, J P, and Erickson, R U, Annals of Internal Medicine, 1966, 64, 293.

26 Wieners, S N, Veacs, V, and Shapiro, H, Radiology, 1969, 92, 110

27 Spiro, H M, and Miles, S S, New England Fournal of Medicine, 1970, 263, 286

28 Gordon, E M, Johnson, A G, and Williams, G, Lancet, 1972, 2, 226.

${ }^{29}$ West, H F, British Medical fournal, 1959, 2, 680.

${ }^{30}$ Canavan, J S F, and Briggs, J D, in Cimetidine, ed W R Burland and M A Simkins, p 75. Amsterdam, Excerpta Medica, 1977.

${ }^{31}$ Grimson, T A, Lancet, 1977, 1, 858.

32 Delaney, J C, and Ravey, M, Lancet, 1977, 2, 512.

(Accepted 28 November 1977)

\section{Hang-gliding accidents}

\section{RAIMUND MARGREITER, LOIS-JÖRG LUGGER}

British Medical fournal, 1978, 1, 400-402

\section{Summary}

Seventy-five known hang-gliding accidents causing injury to the pilot occurred in the Tyrol during 1973-6. Most occurred in May, June, or September and between 11 am and $3 \mathrm{pm}$, when unfavourable thermic conditions are most likely. Thirty-four accidents happened during launching, 13 during flight, and 28 during landing, and

Chirurgische Universitätsklinik, Anichstrasse 35, A-6020 Innsbruck, Austria

RAIMUND MARGREITER, MD, surgeon

LOIS-JÖRG LUGGER, MD, surgeon most were caused by human errors-especially deficient launching technique; incorrect estimation of wind conditions, altitude, and speed; and choice of unfavourable launching and landing sites. Eight pilots were moderately injured, 60 severely (multiply in 24 cases), and seven fatally; fractures of the spine and arms predominated. Six of the 21 skull injuries were fatal.

The risk of hang-gliding seems unjustifiably high, and safety precautions and regulations should be adopted to ensure certain standards of training and equipment and to limit flying to favourable sites and times.

\section{Introduction}

Hang-gliding accidents are increasing with frightening rapidity, but there have been few reports on their epidemiological and 